\title{
Analysing Economic Policies Related to Effects of Immigrant Labour with Case Studies
}

\author{
Prof. Abdol Aziz Shahraki
}

Zahedan city, Iran

\begin{abstract}
When the discussions concerning the migrants are severe in host countries, this paper investigates the profitability or disadvantage of the migrant labour in the regional economies considering the recent structural socioeconomic changes. It studies theories related to the role of migrant labour in the regional micro and macro economies and uses classic methods such as a benchmarking method, an applied mathematical modelling and a case study strategy. Immigrants have entered Iran uncontrolled and populous, particularly when the red army occupied Afghanistan. The presence of the immigrants has had significant effects on the Iranian micro and macro economies. In recent years, the immigration has been banned in the Sistan Baluchistan province, which caused a lower development rate. The mathematical economic model of this paper provides the analysis taking into account some economic indicators. The analysis illustrates differences among three alternatives, namely; with immigrants, without immigrants, and a classic successful economy. The results suggest the use of migrant labour to balance and stable the market and to increase production and wealth.
\end{abstract}

Keywords : Structural changes; Migrant labour; Macro and microeconomics; Bench marking; Economic prosperity

\section{INTRODUCTION}

The migration has always been a factor of civilization exchange and development, but has never been complicated to this degree. For this reason there are a lot of debates about the role of migrants in host countries around the globe, see i.e. (Beyer and Matthes, 2015and Williams and Graham, 2014). The discussions are run while important structural changes such as the impact of the information revolution, globalization, regional and local conflicts, and economic revisions are happening. This process exists in Iran too, particularly owing to its geographical location, neighbourhood with fifteen countries, and access to free waters. During the past four decades, there have been structural changes in all micro and macro systems of Iran. Changes in social structures, demography, culture, beliefs, lifestyles, and economy are some of those (Abounoori, Nazarian, and Amiri, 2014). Since 1956, Iran's urban population has been increasing at the cost of the rural areas. The most important reason for this increase has been rural to urban migration, the internal migration and migrants from neighbouring countries. However, other factors are involved, such as the incorporation of larger villages as cities. Overall one perspective of the change has been the demographic one. "The rural population has declined gradually, falling to 61 percent in 1966, to 53 percent in 1976, to 45 percent in 1986, and to only 38 percent by 1996 and 31 percent in 2006 census" (Azkia and Hooglund, 2011:3). The most common feature of Iranian economic life is the rapid and unsustainable changes. On the one hand, changes in the demography, structure of the workforce, the stagflation, and institutional administrative crises are visible. On the other hand, as Ada, Karaman and Ghaffarzadeh wrote knowledge-based and data-driven orientation of some economic institutions can be seen (Ada, Karaman and Ghaffarzadeh, 2015). Furthermore, in Sistan Baluchistan changes in micro and macroeconomics have been influenced by national macro policies, international relationships, and the presence of immigrants (Shahraki, 2014). This paper analyses the impact of immigrants on the economic life of the province of Sistan and Baluchistan. It studies and compares two situations related to the immigrants, namely the presence of immigrants to the province's micro and macro economies and the absence situation. The first policy was initiated in 1979 and continued until 2000, which was mainly based on the ideology of Islamic brother hood and altruistic feelings. At that time, Iran had only reactions against mass immigration without regard to its economic interests. The second policy has been taken under pressures of many refugees living in the province and their burden on the environment, the natural 
resource, employment opportunities, regional/urban infrastructures, urban spaces, and the provincial security. This policy forbade the presence of foreign immigrants in the province of Sistan Baluchistan. In result, the province has been spared from the negative effects of immigrants, but it has lost some economic advantages. Since the province has been suffering an inequality in development despite its advantages and possibilities the forbidding policy seems to be unfavourable. Developmental inequality of provinces is one recent emerging subject, which caused unfair development among regions and areas. It is why this study will present a fair and reasonable migration policy for development in the province of Sistan Baluchistan. The purpose of this article is to explain and test the hypothesis concerning the usefulness of a regulated use of immigrant labour. The hypothesis is that the province can benefit the migrant labour under umbrella of the national regulations and macroeconomic policies to strength its economy. This theory is based on an assumption that neither an open-door policy concerning immigrants nor an absolute prohibition policy is useful. The research method explores theories related to this problem, performs a case study and builds a mathematical model based on a production function. The model introduces a production function and examines the accuracy of the presented theory in micro and macroeconomics scales.

To perform this research study this paper is divided into seven parts. This first part discusses on the immigration subject and structural changes in socioeconomic features of Iran and Sistan Baluchistan province. This part presents also the applied methods by this study and its hypotheses. Part two is about structural changes in the Sistan Baluchistan province. It studies the recent changes in the concept of the family, the relationships between a family and macro scale socioeconomic regimes, the interaction between knowledge institutions and economic corporations, etc. Part three suggests a rational economic model called for a rational economic model for Sistan Baluchistan, REMSB, to improve the microeconomics and macroeconomics situations of the province with the help of the migrant labour. Part four applies the REMSB in the province's micro economy. This part first studies the behaviour of individual economic institutes such as companies, producers, entrepreneurs, industrial corporations, and service institutes. Then, it recommends some economic techniques to determine the prices and quantities of products at the local markets. The purpose of this part is to teach the economic institutes to survive under difficult situations. Part five is devoted to the application of the REMSB model in the province's macro economy. Similar to the previous part, this part studies first the situations of important macroeconomics indicators in the province. Then it recommends some economic techniques to improve the province's macroeconomics indicators. Again the purpose of this part is to teach the regional economic decision makers to recover the macro indicators in the stagnation crisis. Part six is comparative analysis. This part evaluates the two alternatives, namely with the migrant labour and without the migrant labour having in the assessments a successful classic economy as the basis for the comparisons. Part seven presents the conclusions.

\section{Structural Changes in the Sistan Baluchistan Province}

The Sistan Baluchistan province of Iran is adjacent to Afghanistan and Pakistan. It is at the Oman Sea too. Figure 1 illustrates the place of the province and its regional importance.

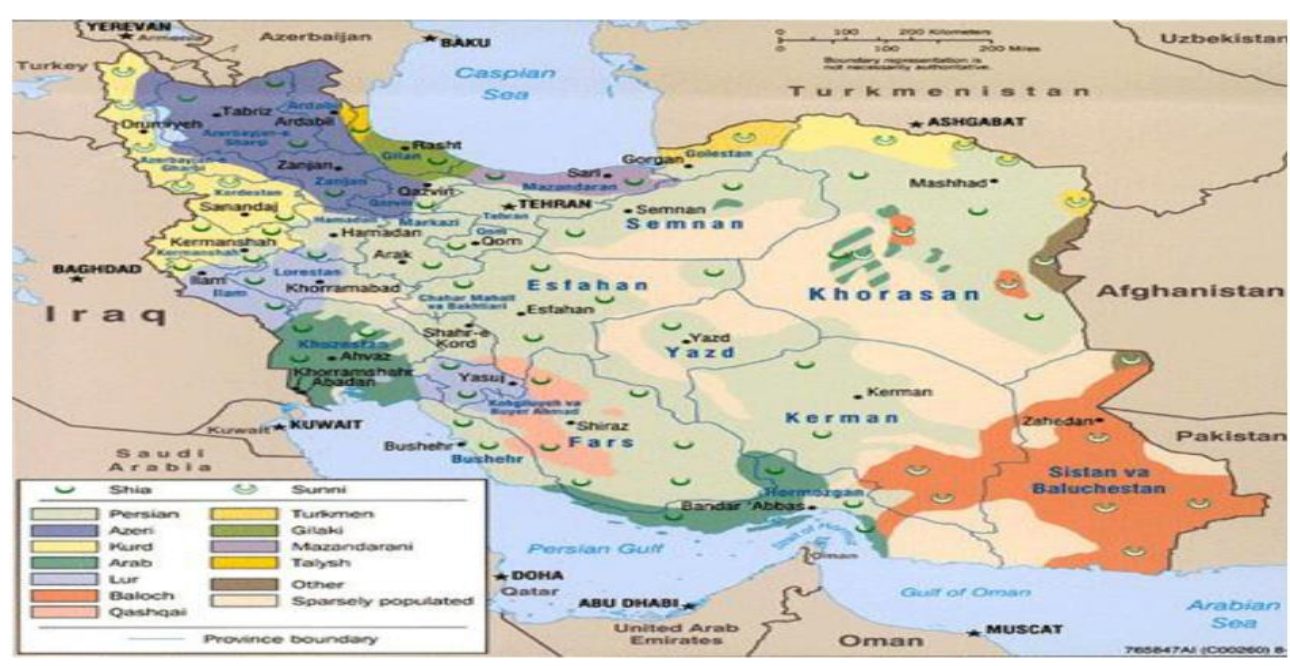

Figure 1. Place of the Sistan Baluchistan province of Iran

Source: Race for Iran 
Aghajanian and Thompson said rightly, that a process of family development has continued in the Sistan Baluchistan province (Aghajanian, and Thompson, 2013). Families in this province have changed over the past four decades. This change includes family formation, household structure, and improved situation of the women, the child well-being, lifestyle, work-life balance, and an overall economic improvement. Important gains in female education investment have contributed to a rise in female employment. Particularly, in the social life the women of the Sistan Baluchistan province have obviously got more active role in the development processes compared to earlier. At the same time, the relation between families and the societies have changed in terms of various economic behaviours. A family is a social group that its characteristics such as the number of its members and their ties, the position of its members, and its stability vary at different times and environments (Creswell, et al. 2015; Antonovsky, 2014 and Kivenzor, 2015). In recent decades, the household management, the family status in the society, and the family values also have been changed. A family as a social micro group has a multidimensional interaction with macro political, macroeconomic and cultural systems of the country. Thus, the family is different in various cultures, economies and eras (Fong and won Kim, 2016). While the social structure progresses from agriculture and animal husbandry production toward industrial production and then postmodern knowledge-based production formations, the traditional concept of family is also changing. In the province's urban communities, the wide traditional patriarchal have inclined towards small families gradually and the father's role is somewhat limited. New economic relations and the current assemblies concerning the various family models also increasingly influence even the same limited role of the father. As mentioned earlier, it was observed that the girls have access to greater social and economic roles. In parallel, they demand more legal abilities to make decisions in their families (Raeisi, 2014). Knowledge-based orienting is another change that the province's economy is experiencing. An essential aspect of the changes is the increasing dependence of economy on knowledge and information. In recent years, efforts to modernize the administrations in economic institutions and banks have been done. Increasing the number of educational institutes and universities resulted many knowledge workers and knowledge networks. Consequently, the relationship between research and development in the province has been spotlighted (Saeedian, et al. 2013). One sign of a knowledge based economy in the Sistan Baluchistan is collaborations among main institutions such universities, industrial enterprises, and government. The official relations provide the province with network data. The knowledge base of the Sistan Baluchistan economy makes social expectations of the economic institutions. Another important change was the presence of immigrants in the economy. Migrants have had an important role in the province's economy, and the evidence shows that still are playing. Economically, the first impact of immigrants is seen in the labour market, which is often based on comparisons of immigrant wages and native employments in this province. Characteristically, immigrants are found to gain lower employment and wages than natives. On the other hand, some more observation found that the concentrated migrant labour in certain sectors of the Sistan Baluchistan economy, such as construction works, mechanical repairs, suitcase trades, and household services has put the native labour under pressure and compete. The majority of less educated native people were annoyed with the presence of the migrant labour in the economy. Second impact has been in the official urban economy as immigrants are more often unregistered, unauthorized, and outside of the official macroeconomic plans. Then, the impact of the immigrants on the native culture, demography, environmental components and natural resources are important too. According to the 1994's statistical yearbook 133,179 people in the province were newcomers immigrants (Statistical Yearbook of Sistan Baluchistan, 1381). It is believed that an unknown number have also entered the province borders unauthorized. Based on the census of 2001, four percent of the population was foreign refugees. Sistan Baluchistan with 376,652 foreign national people is the second host province in Iran. Table 1 shows the distribution of their living cities in the province.

Table 1. The number of immigrants living in cities of the Sistan Baluchistan province

\begin{tabular}{|l|l|l|l|l|l|l|l|}
\hline Name of the city & Zahedan & Zabol & Khash & Iranshahr & Saravan & Nikshahr & Chabahar \\
\hline Number of immigrants & 179404 & 110882 & 37431 & 28032 & 14500 & 2347 & 4056 \\
\hline Total number & \multicolumn{7}{|c|}{376652} \\
\hline
\end{tabular}

Reference: (Statistical Yearbook of Sistan and Baluchistan, 1381) 
Table 2 illustrates the occupied job opportunities by the immigrants.

Table 2. Types of job occupied by migrants per percentages in 1979-1990

\begin{tabular}{|l|l|l|l|l|l|}
\hline Type of jobs & Labour & Technical worker & $\begin{array}{l}\text { Agriculture and Animal } \\
\text { Husbandry Workers }\end{array}$ & Businessman & Services \\
\hline Percentages & 94 & 0.50 & 4 & 0.50 & 1 \\
\hline
\end{tabular}

Reference: (Statistical Yearbook of Sistan Baluchistan, 1381)

Table 3 illustrates the job opportunities were occupied by the migrants at this time.

Table 3. Types of job occupied by migrants per percentages in 1991-2000

\begin{tabular}{|l|c|c|c|c|c|}
\hline Type of jobs & Labourer & Technical worker & $\begin{array}{l}\text { Agriculture and Animal } \\
\text { Husbandry Workers }\end{array}$ & Businessman & Services \\
\hline Percentages & 64 & 19 & 12 & 3 & 2 \\
\hline
\end{tabular}

Reference: (Statistical Yearbook of Sistan Baluchistan, 1381)

Similarly, immigrants were welcomed into the province until the second policy process has been begun. Comparing Table 2 to Table 3 exhibits that the migrants had progressed to occupy better jobs and incomes. The progress happened while the country interred a deep economic crisis and worse that the immigrant activities did not include in the urban and regional economics. Consequently, the presence of the immigrants had been announced an inappropriate and unacceptable policy and it had been stopped. Nobody has done an economic analysis of the economic difficulties that such immigration has been imposed on Iran. Nor has been done an assessment of the benefits immigrants have given the province's economy. Only one report published by the bureau of immigration organization, analysed effects caused by the presence of immigrants in the province (Bureau of Aliens and Foreign Immigrants Affairs). According to the report, some of the negative effects caused by the presence of immigrants in the province were:

- 1,248 illegal marriages

- Occupying 94,079 job opportunities

- The occupation of educational facilities by 263,305 immigrant students

- Problems caused by 500 detained criminal migrants

- Security problems

- Economic problems such as feed and living costs in the migrant camps

- Costs for hygiene and occupied beds in hospitals

- Costs of urban/regional infrastructures such as electricity, water and sewage

- The costs arising from the expansion of the marginalized urban districts and social anomalies

The history of the migration in Iran as well as other host countries has shown that unregistered and illegal migrants convert parts of the economy to the black economy; see i.e. (Kondo, 2016). As noticed earlier, immigrants cause a reduction of wages and the purchasing power of the local people, resulting in a decrease in the welfare of local people. From the other side, immigrants have contributed to macro and microeconomics development in the Sistan Baluchistan province. Immigration microeconomics outcomes in the province have experienced as a significant increase in the proportion of low skilled workers, which contributed to the local production corporations specially agriculture, livestock, food, and even the new built environment development. With the help of the migrant labour small sized production companies could survive despite the stagnation. The implications of the immigration to the macroeconomics have almost been in the favour of the employers and politicians compared to the general population. Nevertheless, there is some evidence to suggest that immigration makes the labour market more flexible and effective in the long perspective to achieve growth and economic prosperity.

From a macro perspective, the migrant labour has also been effective in increasing agricultural and animal husbandry productions at macro scales so that the province could export meat and agricultural productions to other provinces. They also assisted in housing and urban infrastructure projects such 
as road networks. Immigrants almost as labourers and fewer as semi-skilled labours helped the mass buildings in the private sectors and physical development of the province. Migrant labourers usually perform heavy and unsafe jobs with the patience and the ability when the native people do not like to do. From a micro perspective, the migrants were active in housing and services such as repairs and maintenance of houses and household appliances. They showed up talent in activities such as metal turning and mechanics. The migrants have worked in the pastoral livestock sector and domestic cattle in small units or larger semi-industrial units. The migrant labour has benefits for manufacturing companies, especially food production (Bureau of Aliens and Foreign Immigrants Affairs).

\section{RATiOnAl ECONOMic MOdEl OF Sistan BaluChistan, REMSB}

This mathematical model is going to explain the micro and macroeconomics systems in the Sistan Baluchistan province. This model is to analyse the province's economy in two different situations, namely with the presence of the immigrant labour and without it. It also shall apply statistical analysis to predict the future behaviour of the economy in the province. This is a linear model in which the relationships among the parameters are linear, but the relationships among the predictor variables may be linear or non-linear. However, this is a dynamic model because it explains economic behaviours in the time interval. To build the model the classic production function is:

$Q=f(L, C)$

In equation (1), $\mathrm{Q}$ is the production magnitude, $\mathrm{L}$ is work force, and $\mathrm{C}$ is the amount of capital. The assumption is that in certain circumstances of the economy, the production of basic goods, especially food is important. As (1) shows the traditional production function suggests that production is related to capital and labor sources. Earlier, Scientists included the knowledge worker as a variable in the production function (Kobayashi, 1995 and Beckmann, et al. 2012). With the increasing importance of technology and knowledge in the production as well as the importance of the role of immigrants in the economy this model expands the function and includes the migrant worker as an addition variable. Writing (1) to produce $\mathrm{X}$ commodity gives the equation (2).

$\mathrm{Q}_{\mathrm{X}}=\mathrm{f}\left(\mathrm{L}_{\mathrm{D}}, \mathrm{L}_{\mathrm{I}}, \mathrm{K}, \mathrm{C}\right)$

In the production function (2), $Q_{X}$ shows the production of commodity $X, L_{D}$ is the domestic labour, $\mathrm{L}_{\mathrm{I}}$ is the immigrant labour, $\mathrm{K}$ represents the knowledge workers, and $\mathrm{C}$ is the capital. The production function (2) can be written as a linear equation too:

$\mathrm{Q}_{\mathrm{X}}=\mathrm{a}+\mathrm{bL}_{\mathrm{D}}+\mathrm{cL}_{\mathrm{I}}+\mathrm{dK}+\mathrm{eC}$

In equation (3), parameters $\mathrm{a}, \mathrm{b}, \mathrm{c}, \mathrm{d}$ and e will be valued with the help of field experiences and macroeconomics policies. The equation (3) is a production function for one commodity at one manufacture in microeconomics scale. If the above linear equation will be used for producing the same commodity in several places across the province write (4).

$a_{1}+b_{1} L_{D_{1}}+c_{1} L_{I_{1}}+d_{1} K_{1}+e_{1} C_{1} \leq Q_{X_{1}}$
$a_{2}+b_{2} L_{D_{2}}+c_{2} L_{I_{2}}+d_{2} K_{2}+e_{2} C_{2} \leq Q_{X_{2}}$
$a_{3}+b_{3} L_{D_{3}}+c_{3} L_{I_{3}}+d_{3} K_{3}+e_{3} C_{3} \leq Q_{X_{3}}$
$\cdot$
$a_{n}+b_{n} L_{D_{n}}+c_{n} L_{I_{n}}+d_{n} K_{n}+e_{n} C_{n} \leq Q_{X_{n}}$

For the macroeconomic scale the linear equation system (4) has been rewritten in the form of a matrix as follows.

$\left[\begin{array}{c}\mathrm{a}_{1}+\mathrm{b}_{1} \mathrm{~L}_{\mathrm{D}_{1}}+\mathrm{c}_{1} \mathrm{~L}_{\mathrm{I}_{1}}+\mathrm{d}_{1} \mathrm{~K}_{1}+\mathrm{e}_{1} \mathrm{C}_{1} \\ \mathrm{a}_{2}+\mathrm{b}_{2} \mathrm{~L}_{\mathrm{D}_{2}}+\mathrm{c}_{2} \mathrm{~L}_{\mathrm{I}_{2}}+\mathrm{d}_{2} \mathrm{~K}_{2}+\mathrm{e}_{2} \mathrm{C}_{2} \\ \mathrm{a}_{3}+\mathrm{b}_{3} \mathrm{~L}_{\mathrm{D}_{3}}+\mathrm{c}_{3} \mathrm{~L}_{\mathrm{I}_{3}}+\mathrm{d}_{3} \mathrm{~K}_{3}+\mathrm{e}_{3} \mathrm{C}_{3} \\ \cdot \\ \dot{ }_{\mathrm{n}}+\mathrm{b}_{\mathrm{n}} \mathrm{L}_{\mathrm{D}_{\mathrm{n}}}+\mathrm{c}_{\mathrm{n}} \mathrm{L}_{\mathrm{I}_{\mathrm{n}}}+\mathrm{d}_{\mathrm{n}} \mathrm{K}_{\mathrm{n}}+\mathrm{e}_{\mathrm{n}} \mathrm{C}_{\mathrm{n}}\end{array}\right] \leq\left[\begin{array}{c}\mathrm{Q}_{\mathrm{X}_{1}} \\ \mathrm{Q}_{\mathrm{X}_{2}} \\ \mathrm{Q}_{\mathrm{x}_{3}} \\ \cdot \\ \cdot \\ \mathrm{Q}_{\mathrm{x}_{\mathrm{n}}}\end{array}\right]$ 
The above matrix, (5), can be simulated for every $\mathrm{X}$ commodity, which is manufactured in several places in the province. Mixing the matrix rows gives the production function for macro scale producing of the commodity, see (6).

$\sum_{n=1}^{\infty} Q_{X_{n}}=\left(a+b \sum_{i=1}^{n} L_{D_{i}}+c \sum_{j=1}^{n} L_{I_{j}}+d \sum_{m=1}^{n} K_{m}+e \sum_{t=1}^{n} C_{t}\right)$

In equation (6), $\mathrm{n}$ specifies the number of places there the commodity of $\mathrm{X}$ has been producing. $\mathrm{L}_{\mathrm{D}_{\mathrm{i}}}$, $\mathrm{L}_{\mathrm{I}_{\mathrm{j}}}, \mathrm{K}_{\mathrm{m}}$, and $\mathrm{C}_{\mathrm{t}}$ represent the number of domestic workers, the number of immigrants, the number of knowledge workers, and the amount of capital respectively. The next step in the process to build the appropriate economic model is an optimal resolving of the equation (6) as the target function regarding two options. One option is the presence of immigrant labour in the regional economy and another is the absence of them.

$$
\mathrm{Z}=\mathrm{a}+\mathrm{b} \sum_{\mathrm{i}=1}^{\mathrm{n}} \mathrm{L}_{\mathrm{D}_{\mathrm{i}}}+\mathrm{c} \sum_{\mathrm{j}=1}^{\mathrm{n}} \mathrm{L}_{\mathrm{I}_{\mathrm{j}}}+\mathrm{d} \sum_{\mathrm{m}=1}^{\mathrm{n}} \mathrm{K}_{\mathrm{m}}+\mathrm{e} \sum_{\mathrm{t}=1}^{\mathrm{n}} \mathrm{C}_{\mathrm{t}}
$$

To resolve the equation (7) as the target function the following assumptions exist:

$\mathrm{L}_{\mathrm{D}}=\mathrm{pL}_{\mathrm{i}} \quad$ The decision makers in the province will specify the parameter $\mathrm{p}$.

$\mathrm{K}=\mathrm{r} / 100 \mathrm{C} \quad$ The $\mathrm{r}$ is a parameter as above

$\mathrm{P}=\mathrm{RE} / \mathrm{L}_{\mathrm{D}}+\mathrm{L}_{\mathrm{I}}+\mathrm{C} \% \quad \mathrm{P}$ is profit gained by the production and $\mathrm{RE}$ is reduction of production costs due to investment in $\mathrm{R} \& \mathrm{D}$.

$M \leq a+b \sum_{i=1}^{n} L_{D_{\mathrm{i}}}+c \sum_{j=1}^{n} L_{I_{j}}+d \sum_{m=1}^{n} K_{m}+e \sum_{t=1}^{n} C_{t} \leq N$

$M$ and $N$ are maximum and minimum volume of producing $X$ commodity. Thus, the model of REMSB could be introduced as the following equation system:

$$
\left\{\begin{array}{c}
\text { MaximizeZ }=\mathrm{a}+\mathrm{b} \sum_{\mathrm{i}=1}^{\mathrm{n}} \mathrm{L}_{\mathrm{D}_{\mathrm{i}}}+\mathrm{c} \sum_{\mathrm{j}=1}^{\mathrm{n}} \mathrm{L}_{\mathrm{I}_{\mathrm{j}}}+\mathrm{d} \sum_{\mathrm{m}=1}^{\mathrm{n}} \mathrm{K}_{\mathrm{m}}+\mathrm{e} \sum_{\mathrm{t}=1}^{\mathrm{n}} \mathrm{C}_{\mathrm{t}} \\
\mathrm{L}_{\mathrm{D}}=\mathrm{pL}_{\mathrm{i}} \\
\mathrm{K}=\mathrm{r} / 100 \mathrm{C} \\
\mathrm{P}=\mathrm{RE} / \mathrm{L}_{\mathrm{D}}+\mathrm{L}_{\mathrm{I}}+\mathrm{C} \% \\
\mathrm{M} \leq \mathrm{a}+\mathrm{b} \sum_{\mathrm{i}=1}^{\mathrm{n}} \mathrm{L}_{\mathrm{D}_{\mathrm{i}}}+\mathrm{c} \sum_{\mathrm{j}=1}^{\mathrm{n}} \mathrm{L}_{\mathrm{I}_{\mathrm{j}}}+\mathrm{d} \sum_{\mathrm{m}=1}^{\mathrm{n}} \mathrm{K}_{\mathrm{m}}+\mathrm{e} \sum_{\mathrm{t}=1}^{\mathrm{n}} \mathrm{C}_{\mathrm{t}} \leq \mathrm{N}
\end{array}\right\}
$$

The equation system (8) can be used for the analysis concerning the micro and macroeconomics of the Sistan Baluchistan province. By maximizing the production function with respect to the conditional equations that reflect macro policies the effects of the migrant labour will be known. On this way, the validity of the hypothesis that the utility of legal immigrant labour under umbrella of the macro plans contributes to the province's economy will be verified.

\section{THE APPLICATION OF THE MODEL IN THE PROVINCE'S MICRO ECONOMY}

This section explores the behaviour of individual economic entities such as companies, producers and service institutes. It studies also some procedures to determine the prices and quantities of products at the local bazaars. Those procedures, which managers of the manufactures and economic institutions would use to plan the province's micro economy, are as follows.

- Recognizing the target groups (consumers) and analysing their needs. The consumer will decide to buy the produced goods with regard to their preferences and incomes. The consumer's priority curve and the household budget line illustrate the abilities and limitations of the target group to buy a certain commodity (Tamvakis, 2015).

- Modelling the commodities' demand and supply. A supply and demand curve determines the price in the market. These curves assist balancing prices and hence the general market equilibrium. Based on the same curve the production managers can determine the production and supply qualities of goods in the market (Sullivan, 2007). For example, red 
meat market balance in the province of Sistan Baluchistan, which has a key role in providing protein for the whole of the country, is important. This means that the price of this product will not be increased due to external factors.

- Making decisions about the quality and quantity of workers. The production units decide the quantity and quality of their workers on the basis of the economic policies, i.e. the number of required knowledge workers, domestic workers and migrant workers.

- Modelling investments in the corporations. Each producer in the province has three inputs. First, capital and liquidity (Friedman, 1953). Second, tools and technology, and third, workforce. Every corporation inputs appropriately in the three mentioned sectors with the help of adjusting the symmetrical curve of quantity budget. In addition, the corporation realizes that if migrant workers are needed.

Generally, the province's producing companies shall answer questions concerning the determination of supply and demand, the quantity and quality of labour, the amount of capital and liquidity. Those also shall decide whether to continue or to stop the production line in the current stagnant situation. Simulating the model of REMSB can find answers to these problems. For example, they shall answer to the question whether the use of the immigrant labour is beneficial to local producers or not? Now, suppose that a manufacturer in Nikshahr city aims at the highest production capacity of the $X$ commodity. Therefore, it must maximize the production function. By resolving the equation system (8) and finding the unknown variables, the regional companies will have one of the following situations:

- Now, the company gains maximum profit and the average total production costs is less than the price of a product. In this case, the company is in good condition and does not require any immigrant labour.

- Now, the profit is normal, which means $\mathrm{P}=0$. In this case, the company needs the migrant work to increase the $\mathrm{X}$ production and reduce finished costs of the $\mathrm{X}$.

- If the company is at least loss situation, it should continue the production line of the X. By reducing production costs, by using migrant labour, and with the help of mass production the company's economic situation can be improved.

- Now, the loss is greater than the least loss. In this case, the company cannot continue its production line, but it should maintain its presence in the market.

\section{THE APPLICATION OF THE MODEL IN THE PROVINCE'S MACRO ECONOMY}

The province's macroeconomic indicators such as Gross Domestic Production growth rate, per capita income, per capita consumption, per capita savings, the amount of local investment, the amount of international investment, the value of exports, the value of international trade, unemployment rate, and inflation rate have been studied and observed (Dimand, 2008). The REMSB model explains the relationships among the above indicating factors. Some procedures that improve the province's macroeconomics behaviours are:

- Measures for economic growth. The economic growth requires a large number of job creation and price stability. Planning, design and implementation of large infrastructure projects such as railways and water projects contribute to the economic growth.

- Financial reform. Now, it can be seen that manufacturing firms due to the lack of liquidity cannot be entrepreneurs. Modifying the banks and large-scale financing reforms to power those sectors accelerate economic development and growth. In the case of the Sistan Baluchistan province, the theory of monetarism, which Milton Friedman has suggested, may have a helpful role for the liquidity.

- Increasing the province's production and income. From the production perspective the province has great potentials such as fish, shrimp, meat, poultry, grains, vegetables, horticultural crops, palm, mining, rights of transit and borders advantages. These potentials must be realized.

- Declining the current high rates of inflation and unemployment. Inflation and mass unemployment are the characteristics of this province compared to the national average even more 
severe (Golkar, 2012). Only economic prosperity and widespread production and consumption could reduce the alarming rates (Blaug, 1997).

The target function in the equation system (8) reported all sums, which represent the province's macro economy. The model shows that the total production of $X, \sum_{n=1}^{\infty} Q_{X_{n}}$, is related to parameters of $a, b$, $\mathrm{c}, \mathrm{d}$, and e, which the regional decision makers will specify. In addition, the total amount of producing $\mathrm{X}$ commodity is influenced by the domestic labour, $\sum_{\mathrm{i}=1}^{\mathrm{n}} \mathrm{L}_{\mathrm{D}_{\mathrm{i}}}$, the migrant labour, $\sum_{\mathrm{j}=1}^{\mathrm{n}} \mathrm{L}_{\mathrm{I}_{\mathrm{j}}}$, the knowledge worker, $\sum_{\mathrm{m}=1}^{\mathrm{n}} \mathrm{K}_{\mathrm{m}}$, and the capital amount, $\sum_{\mathrm{t}=1}^{\mathrm{n}} \mathrm{C}_{\mathrm{t}}$. The managers of the macro economy will decide the variables with the help of tools, which have been mentioned above. Therefore, the model is applied at the macro scale well.

\section{COMParative ANALYSIS}

In this section, three alternatives are compared. The first is the presence of the immigrant labour, the second is the banning the immigrant labour, and the third is a successful classic economy as the basis for the comparisons. To implement the comparisons a benchmarking method is used, which introduced eighteen indicators. The indicators have been evaluated and scored for the three alternatives with the help of structured interviews and regional cognition. The businesses' manger directors, and academic colleagues were interviewed and their opinions concerning every indicator for every alternative have been written down. Table 4 illustrates the result of the evaluation and scoring process.

Table 4. Evaluating and scoring of eighteen indicators for three different alternatives

\begin{tabular}{|c|c|c|c|c|}
\hline Line & Indicators & $\begin{array}{c}\text { Alternative A. } \\
\text { With immigrant }\end{array}$ & $\begin{array}{c}\text { Alternative } \\
\text { B. No } \\
\text { immigrant }\end{array}$ & $\begin{array}{c}\text { Alternative } \\
\text { C. Optimal } \\
\text { case }\end{array}$ \\
\hline 1 & Migrant workers' social rights & -80 & +25 & +95 \\
\hline 2 & Migrant workers' health and welfare & -60 & +15 & +80 \\
\hline 3 & Social costs such as crime & -33 & 0 & -5 \\
\hline 4 & Security costs & -100 & 0 & 0 \\
\hline 5 & Degradation of environmental components & -33 & 0 & 0 \\
\hline 6 & Reducing natural resources & -33 & 0 & 0 \\
\hline 7 & Occupation of urban infrastructure & -33 & 0 & -5 \\
\hline 8 & Occupation of urban spaces & -20 & 0 & +10 \\
\hline 9 & Wages for workers & -30 & +10 & +25 \\
\hline 10 & Job creation & +30 & 0 & +65 \\
\hline 11 & Physical development of the province & +40 & +10 & +75 \\
\hline 12 & Increasing the income of the community & +30 & +20 & 0 \\
\hline 13 & Housing rent increase & +20 & 0 & 0 \\
\hline 14 & Rising unemployment & +10 & 0 & +75 \\
\hline 15 & Economic prosperity & +20 & 0 & 0 \\
\hline 16 & Increasing Inflation rate & -10 & 0 & +15 \\
\hline 17 & Booming trade market in the province & +10 & +5 & +35 \\
\hline 18 & Booming international trade & +15 & +5 & +460 \\
\hline-- & Total costs & -275 & +90 & \\
\hline
\end{tabular}

Source: Author

As seen in Table 4 that the score due to the social rights of immigrants in alternative $\mathrm{A}$ is -80 owing to the immigrants entered the country without permissions and they were deprived of legal rights. The same index in alternative B has score +25 because of immigrants are safe and their situation has improved compared to alternative A. In the third row, the social costs of crime in alternative A have 33 when around a third of people in the province were the immigrants and at that time, the immigrants have caused one third of economic loss due to this index. Nevertheless, this score is zero in alternative $\mathrm{B}$ because it is assumed that the immigrants are banned in the province. The security index has been scored -100 in alternative A when mass unknown immigrants entered in the province and jumped to zero in alternative B when there is no immigrant here. Similarly, it is calculated that environmental degradation (line five in the table) and loss of natural resources like soil, water and plants caused by poor immigrants are -33. Fifteenth index in Table 4, economic prosperity, shows that mass immigration in the alternative A gives +20 , but alternative B has downed it to zero. However, by learning from successful economies the same index will jump to +75 to influence province's economic 
growth, see the row fifteen in alternative C. Similarly, the internal and external trade indicators at the seventeenth and eighteenth rows vary due to different alternatives related to the role of the migrants in the trades. However, if adopting the optimal policy the score will be up to +15 and +35 . The last row of Table 4 reports the total scores of all indicators for each alternative that is written in the form of equations (9).

$\left\{\begin{array}{l}\sum_{i=1}^{18} A_{i}=-257 \\ \sum_{i=1}^{18} B_{i}=+90 \\ \sum_{i=1}^{18} C_{i}=+460\end{array}\right.$

The bar chart in Figure 2 interprets visually the equations (9) and shows the sums of costs for the three alternatives.

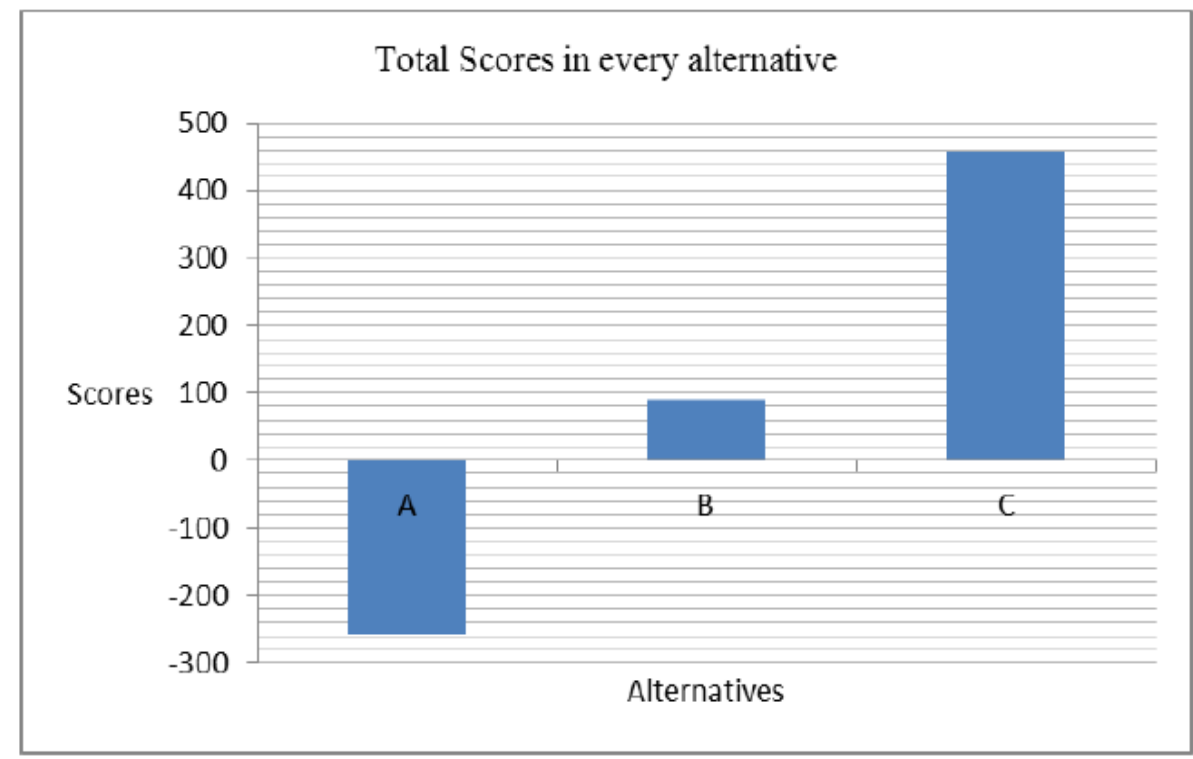

Figure 2. Sums of costs for every alternative separately

Source: The author

Simulating the model by harnessing the experience of successful host economies and considering the province's specific characteristics assists economic prosperity and development. Figure 3 illustrates the economic growth with the help of the alternative $\mathrm{C}$ so that the situation has been improved from 275 in the alternative A up to +460 in the alternative $C$.

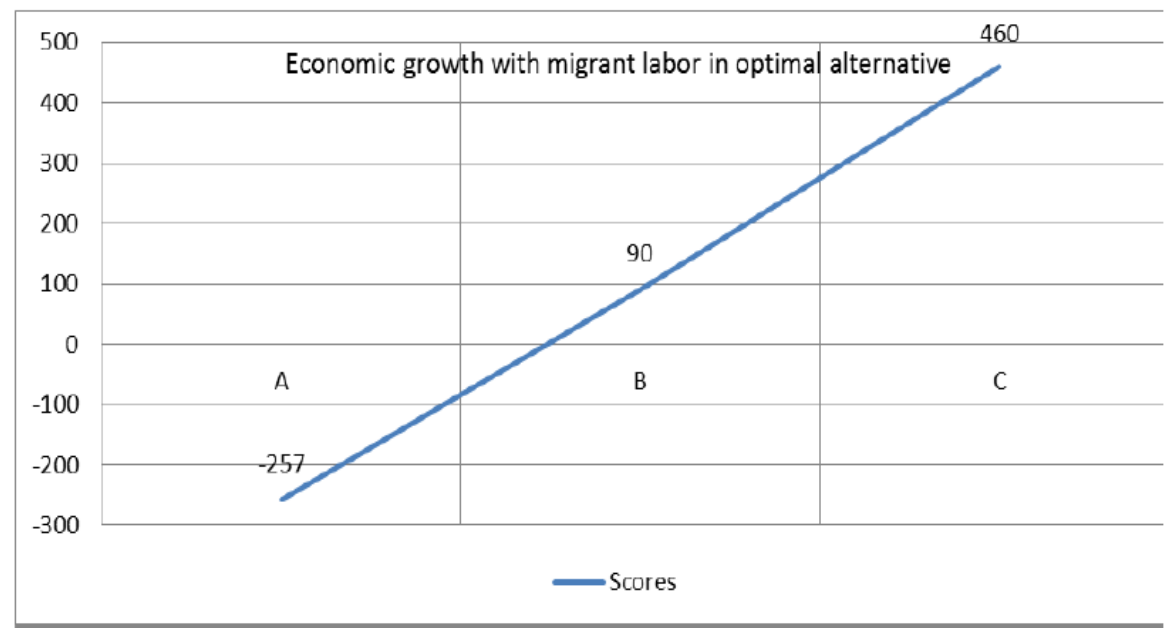

Figure 3. Economic improvements with application of alternative $C$

Source: The author

In the figure above, the optimal alternative, alternative $\mathrm{C}$, uses the migrant labor under umbrella of national and provincial macroeconomics and microeconomics interests. 


\section{Conclusions}

This paper discussed on recent structural changes caused the immigration and explored the positive and undesirable impacts of immigrant labour on the regional economy to answer the question whether the use of the migrant labour for the economic growth and development is useful or not? The case study carried out in the Sistan Baluchistan province to investigate the effects. The case study analysed two policies, which the province has experienced, namely using the migrant labour and banning it. The case study analysed the province's micro and macro economies and presented some procedures as assisting tools to overcome the current stagnation situation. A benchmarking method is used to compare three alternatives. Those alternatives were using the migrant labour, banning it, and a successful economy. To perform the comparisons the technique of structured interviews together with local knowledge and cognition has been used. With the help of the methods the eighteen indicators in each alternative have been valued and scored. These scores represented the magnitudes of costs imposed on the province's economy through every alternative. Aftermath the analyses, it has been found that the use of the migrant labour in the framework of national laws and policies can lead to the development and prosperity of the regional economy. That's why the alternative $\mathrm{C}$ as a desirable option was suggested. When the debates are all about profits and losses caused by the immigrant labor, the investigations and the results of this study can help in this matter. The model presented in this article can be useful everywhere.

\section{REFERENCES}

[1] Ada, Ş., Karaman, E., \& Ghaffarzadeh, M. (2015). Decision Making Based on Management Information System and Decision Support System. Journal for Studies in Management and Planning, 1(3), 206-217.

[2] Aghajanian, A., \& Thompson, V. (2013). Household Size and Structure in Iran: 1976-2006. Open Family Studies Journal, 5, 1-9.

[3] Antonovsky, A. (2014). Intergenerational networks and transmitting the sense of coherence. Life-span Developmental Psychology: Intergenerational Relations, 211.

[4] (Azkia, M., \& Hooglund, E. (2011). Rural Development in Contemporary Iran 1950-2010. International Journal of Social Sciences, 1(3), 223-239.

[5] Beckmann, M. J., Johansson, B., Snickars, F., \& Thord, R. (Eds.). (2012). Knowledge and networks in a dynamic economy: Festschrift in honor of Åke E. Andersson. Springer Science \& Business Media.

[6] Beyer, A., and Matthes, J. (2015). Public Perceptions of the Media Coverage of Irregular Immigration Comparative Insights From France, the United States, and Norway. American Behavioural Scientist, 0002764215573253.

[7] Blaug, M. (1997). Economic theory in retrospect. Cambridge university press.

[8] Bureau of Aliens and Foreign Immigrants Affairs. Available at: http://bafia.moi.ir/Portal/Home/

[9] Creswell, Kasey G., Aidan GC Wright, Wendy M. Troxel, Robert E. Ferrell, Janine D. Flory, and Stephen B. Manuck. "OXTR polymorphism predicts social relationships through its effects on social temperament." Social cognitive and affective neuroscience 10, no. 6 (2015): 869-876.

[10] Dimand, R. (2008). Macroeconomics, origins and history of. The New Palgrave Dictionary of Economics

[11] Fong, V. L., \& won Kim, S. (2016). Perspectives on Chinese Children, Youth, and Education. A Companion to the Anthropology of Education, 18, 333.

[12] Friedman, M. (1953). Essays in positive economics. University of Chicago Press

[13] Golkar, S. (2012). Paramilitarization of the Economy: The Case of Iran's Basij Militia. Armed Forces \& Society, 0095327X12437687.

[14] Kivenzor, G. J. (2015). Cultural dynamics and marketing strategies for emerging markets: characterization of group subcultures and consumption preferences. AMS Review, 1-17.

[15] Kobayashi, K. (1995). Knowledge network and market structure: an analytical perspective. In Networks in Action (pp. 127-158). Springer Berlin Heidelberg.

[16] Kondo, A. (Ed.). (2016). Citizenship in a Global World: Comparing Citizenship Rights in Ten Countries. Springer.

[17] Race for Iran, Sistan Baluchistan map, Available at: http://www.raceforiran.com/2009/10/page/5

[18] Raeisi, M. (2014). A history of active participation of Baluch women in Iranian society: before and after the Islamic revolution. Indian Journal of Scientific Research, 5(2), 63-70.

[19] Saeedian, S., Sabouni, M. S., Shahraki, J., Moradi, E., and Sepahi, M. (2013). Relationship between MetaTechnology Ratios and Varietal Differences in Date Production (Case Study of Sistan and Baluchestan, Iran). International Journal of Agricultural Management and Development (IJAMAD), 3(2). 


\section{Analysing Economic Policies Related to Effects of Immigrant Labour with Case Studies}

[20] Shahraki, A. A. (2014). Sustainable new towns in Iran: Reflections on problems and practices of urban planning and design using case studies.

[21] Statistical Yearbook of Sistan and Baluchistan (1381), available online at: http://amar.org.ir/english/IranStatistical-Yearbook

[22] Sullivan, A. (2011). Urban economics. McGraw-Hill/Irwin.

[23] Tamvakis, M. (2015). Commodity trade and finance. CRC Press. Accessible online at: http://www.sbportal .ir/fa/ostandari/amar/sallnamesb-

[24] Williams, C., and Graham, M. (2014). 'A World on the Move': Migration, Mobilities and Social Work. British Journal of Social Work, bcu058.

Citation: Prof. Abdol Aziz Shahraki. " Analysing Economic Policies Related to Effects of Immigrant Labour with Case Studies" International Journal of Research in Sociology and Anthropology (IJRSA), vol 3, no. 4, 2017, pp. 43-53. doi:http://dx.doi.org/10.20431/2454-8677.0304005.

Copyright: (C) 2017 Authors. This is an open-access article distributed under the terms of the Creative Commons Attribution License, which permits unrestricted use, distribution, and reproduction in any medium, provided the original author and source are credited. 